\title{
INTERPRETING RUH AS AN ECOLOGICAL SPIRITUALITY IN RELATION TO ISLAM AND JAVA MYSTICISM
}

\author{
Vbaidillah \\ UIN Sayyid Ali Rahmatullah Tulungagung \\ Email: ubaidillah830@gmail.com
}

Received: September 8, 2020

Accepted: February 3, 2021

\section{Abstract}

This research aims to explain about the acculturation of Islam and Javanese wisdom in interpreting ruh (spirit) as an ecological behavior in dealing with natural disaster and exploitative activities. The concept of spirit refers to the awareness to interpret the relationship between human and nature as a living macrocosm unit. The awareness, in Islam, is a Sufi dimension of Sufi that blends with nature, such as Javanese philosophy on the principle of the unity of nature. It employs descriptive analytical method by integrating theo-sufistic paradigm to find a turning point in the common ground between Islam and Java in preserving the nature. The analysis goes into three conclusions: 1) the concept of spirit in Islam is a representation of one's love with nature as the manifestation of love with God in its essence; 2) Javanese's beliefs and rituals in ruh as a living and valuable existence signified in mystical mythology known for being haunted and sacred serves as theo-sufistic expressions of Islam and Java; 3) spirituality of the spirit generates awareness of the philosophy of Sangkan Paraning Dumadi, to live in harmony and balance between humans and nature.

Penelitian ini ingin menjelaskan tentang akulturasi Islam dan kearifan Jawa dalam memaknai ruh sebagai perilaku ekologis dalam menangani kerusakan alam dan aktivitas eksploitatif. Konsep ruh yang dimaksud adalah kesadaran 
memaknai hubungan manusia dan alam sebagai satu kesatuan makrokosmos yang hidup. Kesadaran tersebut dalam Islam merupakan dimensi sufistik yang menyatu dengan alam sebagaimana falsafah Jawa tentang prinsip kesatuan alam. Penelitian ini menggunakan metode deskriptif analitis dengan pendekatan integratif dalam paradigma teo-sufistik untuk menemukan titik balik persamaan persepsi antara Islam dan Jawa dalam memelihara alam hayati. Hasilnya, pertama, konsep ruh dalam Islam adalah representasi dari mencintai alam sebagai manfestasi mencintai Tuhan dengan dzatnya. Kedua, keyakinan dan ritual yang dilakukan masyarakat Jawa atas ruh sebagai eksistensi yang hidup dan memberi manfaat yang mewujud dalam mitologis mistik yang disebut angker dan sakral sebagai ekspresi teo-sufistik Islam dan Jawa. Ketiga, spiritualitas ruh memberikan kesadaran dalam filosofi Jawa tentang Sangkan Paraning Dumadi sebagai makna hidup untuk dapat serasi dan seimbang antara manusia dan alam.

Keywords: integration of Islam and Java; ecology; spirit; sSufi

\section{Introduction}

Ecological damage and criminal threats cannot lower the rate of natural disaster. It brings about an anthropomorphism ideology, leading people into the pragmatic way of utilizing natural resources. Relational patterns of subjects and objects between humans and nature have resulted in exploitative behavior as an integrated macro-microcosm concept. Besides, in the modern era, spirituality does not perform as a release of the complexity of life for a momentary concern, but to turn on the fitrah (purity) energy in the spirit to "to be" The Creator's purpose, not to master or "to have" (Naim, 2013).

Therefore, since 1980s, the world community has felt an unconducive climate change to the macro-survival of humans and natural biota on land and sea. These concerns prompted environmentalists to make the first deal in 1992 initiated by the United Nations (Declaration Rio de Janeiro, 1992). The meeting purpose was a part of the earth's rescue and destruction that directly impacted human existence. Thus, preserving the living nature is a part of the faith in Islam, or a home for the indigenous people of Java.

The lack of ecological awareness affects ecological damage for technological development, population growth, and economic motives. However, the fundamental lost is the reduction of the value system of the theological pathology. The normative and dogmatic value of human and environmental relation is interdependent. The dimensions of human unity with the natural environment are manifested in the space of life that affects each other for 
survive and welfare. Sharia calls it hifdzul bi'ah, the ethos and awareness of maintaining the environment. Ecosystem sustainability is the manifestation of the basic principles of religion or maqasid al syaria.

At the same time, the indigenous people of Java hold an intense symbolic awareness through mythological practices leading into the safe and comfortable ecological spaces. They hold ancestral origins, with a strong relationship to the environment. Also, the value system is upheld to determine the economy, politic, social, and law, such as Slametan, an indigenous practice of gratitude for Javanese to maintain a balanced human and natural existence (Setiawati, 2019). The local wisdom can potentially conserve by objective truths instead of tendencies to counter-heresy or polytheism. Digging the awareness can be traced through the interrelation of Islamic spirituality and Java wisdom to preserve nature and environment.

The spiritual dimension of Sufism in Islam appears in the practice of bringing humans to get closer to God and encouraging their perception on nature as living things. Likewise, in Java, someone will never be the true Javanese if $\mathrm{s} /$ he does not apply an ethic and culture. Both are in the same mysticism as the concept of self-control and establishing core personalities. Thus, mysticism can influence human morality (Sartini et al., 2016; Koch, 2020), for example, the role of mysticism in maintaining harmony between religious communities, such as Islam, Christian, and other religions (Wahidi, 2013).

If mysticism can lead to harmonious social behavior, it could also build awareness of ecological behavior. In Java, avoiding disputes and differences means wise, that they can live in a balanced and harmonious manner under propriety (Kholil, 2007). That is why, Javanese greatly concern on the balance of ecosystems for spiritual basis, not juridical. The issue of natural destruction cannot be resolved without a global-holistic vision strategy approach at the level of policy makers and the local solutions' availability in practice (Mangunjaya, 2007). Therefore, this research explains and proves how Islamic and Javanese spirituality aspects are delivered to theo-ecology in the tradition of mysticism for Islam and Java. It examines the point of intercession of Islam and Java in understanding spirit as the essence of rationing ecological values.

\section{The Mystical Paradigm of Ruh in Islamic and Javanese Belief}

The basis for mysticism in Sufism is ruh (spirit) besides zuhud (leaving the pleasures of the world), wara' (pious), and so on. The spirit in Islamic literature is also known as nafs which means soul. Although the Qur'an sees 
nafs has a wider charge of meaning, soul and the spirit are instruments of generating morality in life (Asriyah, 2010). Whereas, in Mu'jam wa Tafsir li Kalimat al-Qur'an, it refers to something which has a life sourced from God. Thus, spirit is absolute, hidden, and tender as the revelations of the prophets (Al-Jamal, 2003: 226).

The word ruh (الروح) in the Quran is found in some surah through keywords, such as ruh ( (روح)rawahu (رواح) riyah (روياح) rihun and (ريحان) nafsun (نف). In the book of Mu'jam al Mufahras li al Fadzi al Qur'an, the keyword ruh (روح) is repeated thirty times while (ريح) is repeated nineteen times, (ريح): (ريح) is twelve, and (ريحان) is twice. It is explained in An Nahl:6, Saba':12, Yusuf:87, Al Waqi'ah:89, Al Baqarah:87/164/253, Al Maidah:110, An Nahl:2/102, Al Isra':85, As Syu'ara:193, Ghafir:15, Al Mujadalah:22, Al Ma'arij:4, Al Anbiya:81/91, At Tahrim:12, As Sajadah:9, Al Hijr:22/29, Shad:36/72, Al Imran:117, Yunus:22, Yusuf:94, Ibrahim:18, Al Isra':9, Al Hajj:31, Syura:22, Al Ahqaf:24, Az Dzariyat:41, Al Haqqah:6, Ar Rum:51, Al Ahzab:9, Fusshilat:16, Al Qomar:19, Al Anfal:46, Al A'raf:58, Al Kahfi:45, Al Furqan:48, An Naml:63, Ar Rum:46/48, Fathir:9, Al Jatsiyah:5, Ar Rahman:12 (Baqi', 1945: 326).

While in Mu'jam al Mufahras li Ma'ani al Qur'an, Sibam Rusydi Zeini focuses on discussing the form of the word ruh (رو ح) in An Nisa' [4]:171, Yusuf [12]:87, Al Hijr [15]:29, An Nahl [16]:2, Al Isra' [17]:85, Maryam [19]:17, Al Anbiya [21]:91, As Sajadah [32]:9, Shad [38]: 72, Ghafir [40]:15, Syura [42]:52, Al Mujadalah [58]:22, At Tahrim [66]:12, Ma'arij [70]:4, An Naba' [78]:38, Al Qodar [97]:4 (Zaini, 1995: 516). On the other hand, Rusydi Zeini refers the word nafs (نف) to ruh (روح) in Surah At Tawbah. In the Arabic dictionary, the word ruh has several meanings based on the pronunciation. The word ruh (روح) can also be rihun (ريح), which is wind and rawhun (روح)) which is grace (Isfahani, n.d.: 206). In the view of Sufism, the word ruh has physical and metaphysical meanings; the first is related to medical while the other meaning as a whisper of rabbani who can know all things and can capture all understandings (Jumantoro \& Amin, 2005).

Similarly, the meaning varieties of ruh are derived from the Qur'an, such as the word ruh with dhamir ilahi means glory, greatness, in Shad:72, As Sajadah:9, Al Anbiya': 91, At Tahrim:12, Maryam:17, and ruh with minhu means fortitude in An Nisa':171. The meaning of ruh followed by dhamir has other meanings, such as ruh with min amri means Qur'an, in Al Mu'min:15, Asy Syura:52; ruh which added qudus means Amin, Jibril's revelation bearer in Al Ma'idah:110; and ruh added malaikat means good deed (amal sholeh) in 
Al Ma'arij:4 and An Naba':38. Thus, ruh is the sacred manifestation of God with all His goodness, which can directly motivate humans' morality and wisdom. Even the closeness of the spirit to God as a bond of ownership does not belong to a nature, God has the power over the spirit to remove or uproot it and give it the divine nur (Taymiyah, 1988).

Ruh is سر الرب ونفخه في أبي الخليقة آدم عليه السلام (manifestation of God given to the prophet Adam). No one knows the true ruh except Allah (Abdullah, 2003: 9). In the human side, ruh is given to human when s/he is inside his/ her mothers' fetus as a creature and a servant who serves for God. Therefore, ruh is the only essence in man closest to truth and chastity.

Imam al Jurjani explains that human's ruh is gentle and nobler than that of other beings, such as animals. Meanwhile, Ibn Arabi argues that ruh is a soul. Sibawaih in Abu Ubaydah tells that Arabs call ruh is for man, animal, and jinn. However, it is different from a soul whose existence does not stand alone, but it ties to others. Confirmed by Imam Ghazali, ruh has two meanings, the manifestation of rabbani and a gentle essence that can motivate human to do good. Therefore, one needs to purify him/herself with worship to raise ruh rabbani' degree (Amen, 2018: 10).

According to Muhammad Mahmud Abdullah, ruh has a diverse dimension of meaning that refers to chastity in the Qur'an, such as Ruh as the meaning of the Holy Qur'an in Asy Syura:52, Ruh as the messenger of the Prophet and Rosul in Ghafir:15, An Nahl: 2. Ruh as (Ruhul amin) Jibril in Asyu'ara:193/194, An-Nahl:102. Scholars of tafsir see the word ruh as an angel who comes to Sitti Maryam, in An Naba':38, al-Qadr:4, Maryam:17/18. Ruh refers to the Prophet Isa directly, in An Nisa':171. The diverse understanding of ruh shows that it is a sacred essence which liberates from bondage the lusts that tend to spoil, and the glory from the nature of bad morality.

The theological approach above denotes that human in its existence consists of physical and soul (al-ruh) dimensions. So, ruh is a positive energy (fitrah) to lighten the behavior and human's view to judge between good and bad when it acquires light. If ruh can lead to thinking and actions, and also if it is filled with love, one's attitude shows love. Al-Farabi contends that ruh is ruhani that can move and think about determining one's direction (Nasution, 1999). Thus, damaging nature for wealth is not the reflection of ruh, but it is lust. In the dimension of tasawuh, ruh can balance the relationship between human, nature, and God in transcendental interdependence. Any effort of human should promote two dimensions at the same time, which are utilization 
and maintenance. Javanese call them the awareness process on sangkan paraning dumadi (origin and purpose of life).

Ruh inflation in the ecological spiritual is essentially a rallying point as the essence created and brought to life under God's will. Thus, the form, function, and maintenance are entirely under His power. This is theoretically justified in al Jatsiyah:13, that the whole thing on the sky and earth is derived and sourced from it. In addition, interdependent forces are formed between ruh and all nature to influence each other.

According to Ibn Qayyim al-Jauzi, ruh is a revelation, in as-Shadura:52 and Ghafir:15. It enlivens the hearts and other spirits. Besides, it generates strength, commitment, and help for believers to do something, in al Mujis:22. Ruh can also be an angel of Jibril, the matter of God, the prophet Isa, and Bani Adam (Jauzi, 1441: 446-447). It indicates that ruh is subtle, which moves human to act properly according to its purpose. The happiness of ruh comes up when it can incorporate pleasure, empathy, and happiness in another soul (Quthb, 2012: 33). Therefore, ruh leads human to social and environmental goodness to beatify soul.

In Javanese perspective, there is a belief that the connectedness between the visible realm (skala) and the invisible one (niskala) is inseparable. This belief is interpreted in Javanese rituals to objects considered to have invisible powers including the wild, such as forests or large and lush trees. Durkheim denotes, "all religion struggles to conceive the inconceivable and to express the inexpressible, an aspiration towards the infinite". The belief generates the term roh as a way of identifying objects or places which have an invisible dimension. Something invisible in Javanese belief could refer to jinn and other invisible beings (in Muqoyyidin, 2013). To obtain the safety, Javanese conduct slametan ceremonies to always associate every invisible realm with the power of either objects or sacred places through guardian spirits to gain strength.

The belief in the invisible (ghaib) power signifies ecological behavior known as sacred to the objects, places, and trees. For example, the prohibition of cutting down trees indiscriminately or visiting certain forbidden places, speaking impolitely, being arrogant, and avoiding certain some attributes to use. Therefore, it is necessary when ecological behavior is a part of the Javanese belief system as a sacred place.

Existentially, Javanese have an emotional closeness to the forest, so the forest affects the value system of Javanese society as the home of the world with various mythologies surrounding. It is a fundamental civilization of Javanese 
that its existence becomes central. It is not only the satisfaction of life, but the aesthetic and spiritual value as a mirror of the world beauty and mental peace. The simple conceptualization of ecosystems among Javanese society is a logical consequence of belief in spirits or delicate beings in haunted or sacred identities.

Ancient Javanese believe that to get spared the disturbances and threats, they must build harmony with the spirits in the ritual of slametan. It is the way Javanese look for safety. Hence, after the arrival of Islam, it is united with the lives of religious people in prayer and followed by eating together. Also, it aims to maintain the order of public behavior in consideration of sacred things (Rosyidi, 2012).

\section{The Interpretation of Mysticism: Javanese Islam in Ecological Representations}

The anthropomorphic or homocentric understanding that places humans as rulers has encouraged exploitative attitudes as ideological truths. In fact, as a biotic creature, human is actually a unit of the macrocosm ecosystem (Rahmadi, 2014: 10). The causes of damage are very diverse from pollution, land misuse, and natural resources depeletion. Javanese uphold the philosophy of rumangsa melu anduweni, wajib melu angkrungkebi (sense of belonging, taking a part in maintaining). The meaning of the philosophy is very relevant in the guarding the nature from any destruction nowadays.

One of dialogueist islamic and Javanese religious practice has appeared to a new concept of religious practice, Islam Jawa, as a representation of high tolerance. The spiritual representation becomes more synchronous. This is also what sets it apart from the integrative model of Malay Islam (Sumbulah, 2012). Even, the cultural exchange is not just a dialogueist but also dialectic which brings about ritual and spiritual of Islam Jawa or Islam Nusantara (Muqoyyidin, 2012; Rubaidi, 2019). One of the dialogist model marks a spiritual understanding of ecological behavior. It can be found in the teachings of Sufism in Islam and Javanese mysticism. Both have something in common about the unity of human entities and God (Zakub et al., 2018).

In Islam, the consciousness of unity appears in the concept of wahdat al-wujud (unity of existence), for example tasawuf behaviors such as zuhud, wara', faqir, fana'-baqa', and insan kamil. The understanding of zuhud means not to associate the heart with the pleasures of the world, so we need to take the distance with the reality of the world. Wara' is a cautious with syubhat 
(confusion between halal and haram). Faqir means feeling enough and not following the whole desires. Fana'-baqa' is an attitude of self-alienation into God's existence, so what arises is only obedience to God, which is not on material. Insan kamil is the culmination of self-purification process by personality as well as the nature of God's name (Zuhri, 2010: 6-8). Spiritual behavior can control the lusts of greed and consumerism, so it assumes the pleasures of the material that are only temporary, and there is an awareness that nature as proof of God's existence.

Javanese mysticism is also very deep in interpreting the philosophy of life purpose, and human relationship with God in the dimensions of harmony and spirituality through the process of soul or nafs in delusion and spirituality. Those two keywords in Javanese view are the life regularity structured and organized neatly as a part of destiny, so they just serve out and maintain the balance created. At the same time, the greed is an inherent part of the sprituality dimension over the God's manifestation, so the entire macrocosm realm is God itself that is immanent. To bring harmony to life in and outside of Javanese, we need to simply and solely believe in mysticism, not the mystical practice.

Mysticism practice of Javanese society is known in laku tradition, prayer and sense in presenting the oneness of God in the concept "ngelmu sangkan paraning dumani" and "manunggaling kawula Gusti". The first concept appears in the awareness of mentality in memayu hayuning buwana, which means the meaning of self in micro and macrocosm harmony as ngelmu (wisdom). Therefore, it is no wonder that Javanese always maintain balance with the universe. Another consciousness is a space dimension called sedulur papat lima pancer that binds human as a unit of the universe to the inner stage wudhar or mukasyafah, which means that the whole entity of nature is the manifestation of God. This is where the concept of unification in Javanese arises which leads to ecological behavior.

Acknowledging the manifestation of God in human and the universe is unraveled in Ranggawarsita explanation in Suluk Saloka Jiwa about the concept of sesotya (values) and embanan (rules) (Nashichuddin, 2006). As a creature, human is in a circle of life between human and the universe. Human and his senses is granted the ability to think, to distinguish his type, his inherent roles, and responsibilities so that he/she is called human being or super human. The great mission of religious learning, which is the relationship of human with God (hablum minallah), God with human (hablum minannas), and human with 
the environment (hablum minal biah), has positioned human to higher degree than other beings. It means that human carries a message of religious morality with its morality function. Durant argues that "religion has a hundred souls. All things passed away will leave forever, except religion" (in Ikhwan, 2003).

Spiritualist human with the essence of love for all beings, especially in the dimensions and ecological functions is depicted in the Qur'an such as; Al-Baqaraah:251, al-A'raf:24, al-Isra':14, al-Hajj:5/32, an Nur:41/46, al-Ahqaf:3, Ar Rum:8, Ar Ra'du:2. One verse directly implies the proper use of nature: "It is He (Allah) who has made the earth a resting-place for you, and the sky a canopy, and sent down water from above wherewith He brought forth fruits for your sustenance. Do not, then, set up rivals to Allah when you know (the Truth)" (al-Baqarah: 22). Meanwhile, the hadith also affirms the concept of ecology: "And when the time of doomsday, and there is date-palms in your hands, plant it immediately." (HR. Ahmad). The verses above confirm that the universe and the contents praise to God, so all the characteristics of life are inherent in plants, good trees growing big, tall, and withered are parts of the spiritual value of submission and servitude to God.

On the other hand, the legal and formal perspective of the laws governing the environment is explained in UU No. 4 of 1982 concerning environmental management (UUPLH-1997) and UU No. 32 of 2009 concerning protection and management of the environment (UUPPLH-2009). Both laws affirm the guarantee of a good life fulfilled with clothing and food centered on the goodness of nature (eco-centric) and that will leave anthropocentrism (centered on humans). Ecology is a form of equating perception and harmony as it equals to the reciprocal relationship between living organism groups to their environment (Akib, 2014: 3; Warassih \& Fatimah, 2018).

Juridically, Article 1 number 7 UUPLH-2009 explains that the environment has certain limits in human influence on the environment or known for carrying capacity. The imbalance in the environment will cause natural damage, such as landslides, floods, drought, and so on. Likewise, Article 40 section 2 states that "anyone who deliberately commits an offense as intended in Article 21 section (1) and (2) Article 33 section (3) is convicted to imprisonment for a maximum of (5) years and a maximum fine of Rp. 100,000,000.00 (one hundred million rupiah). This article is related to Forestry Crime Article 78 section (1) with Article 50 section (1), which states that "anyone who deliberately destroys forest protection infrastructure and facilities is convicted by a maximum of 10 years and a maximum fine of Rp. 5,000,000,000 '(Ali \& Elvany, 2014: 33). 
The clearing of forest has turned into agriculture resulting in low groundwater absorption areas providing many benefits for human needs from kitchen needs to irrigating agricultural and plantations. Besides, the widespread illegal logging is a major factor of the flash floods that devastate agricultural villages that fail to harvest due to submerged in rainwater and many others. Environmental damage is caused by sophisticated technology through industrial development using nuclear power and factory waste. It also includes the factor of low education quality and poverty, that encourage people to exploit nature and reforestation. Thus, the actual use of the environment must be oriented towards humans' integrative economic, social and ecological interests and spiritual goals.

Natural Resources Law exists in the legislation of RI UU No. 41 of 1999 substitute No. 5 of 1967 on forest management, utilization, rehabilitation, protection and conservation: "forest is a unit of ecosystems in the expanses of land containing biological natural resources dominated by trees in the natural environment that cannot separate from each other. Forest management is based on the benefits and sustainability, popularity, justice, togetherness, openness, and cohesiveness" (Rahmadi, 2014: 164). Meanwhile, the strategy for the Conservation of Natural Resources and Ecosystems is in accordance with UU No. 5 of 1990, Article 45 section (1) which discusses forest utilization, Article 44 section (1) concerning restoration of forest functions, and strengthened in Articles 46 and 47, the prohibition of destroying forests in Article 50 with provisions of criminal law and prison in UUPLH-2009 Article 97 to Article 120. Thus, the function of the law for living nature aims to maintain the balance of the ecosystem.

On the other hand, the role of indigenous people in carrying out nature conservation with local wisdom is as important as designing positive laws about protecting nature. The customary law, according to Edward Goldsmith, is in harmony with the earth happened before the manifestation of various laws and regulations, which is the culture of the community around archipelago called "chthonic". The term comes from the Greek khton or khthonous, which means earth. It is used to describe the indigenous traditional law model of the archipelago. It shows how people have a refined view to build harmony with the earth, called nature conservation (Lukito, 2008).

In customary regulations, a sanctum means sanctions which aims to provide lessons and a deterrent effect for violators and destroyers of nature. For example, Balinese custom has two terms, sanksi skala (material sanctions) 
and sanksi niskala (immaterial sanctions) as a logical consequence of the Tri hita karana. It teaches the integration of cosmic relationships, the balance of human relationship with God, with other humans, and humans with environment. In Balinese custom, many terms are used for the sanctions, such as Prayascita, Pemarisuddhan (traditional village cleaning ceremony), Dedosan (fines), Mengaksama, lumaku, ngidih-olas (apologize), Metirtagemana/metirta yatra (customary sanctions for clergy), Meselong (thrown into lua Bali), Merarung/ Mapulang kepasih (drowned in the sea), Meblagbag (tied), Katundung (expelled), Kerampang (stolen property), Kasepekang (not spoken to, not getting notification of community activities) and others (Surtha, 2015: 3-4).

Based on the above perspective, the existence of customary sanctions or customary correction maintains a balance, not only in the sense of humanism but a mysticism. It proves that local or customary law is not the creation of a rational, intellectual, and liberal mind, such as the Western way of thinking, but the creation of a communal, magical, and religious mind, or a cosmic communal. Therefore, obedience to customary law is not just a matter of appropriateness and compliance with legal material but more as a manifestation of sacred essence. It is because the peak of Javanese teachings, which are Buddhist and Hindu preferences, is self-authenticity and self-purity. Even, when the acculturation process of Islam and Javanese, customary law in the context of nature conservation is a process in the dimension of oneness with God (Khalimi \& Khaer, 2013; Purwadi, 2011; Afrianti, 2019). Therefore, Java knows pamoring-kawula gusti in which nature is a part of God's existence.

Unifying with nature in Javanese custom is to have love with God, especially when the acculturation of Java and Islam influences the philosophy and teachings of a more mystical spiritual style. It is called a cosmic-magical relationship that engenders to environmental ethics. Thus, the approach of religion and belief becomes a means of control for the continuity of order and balance of life.

In Arabic it is called 'Urf or 'Adah which means habit, yet this definition in the use of custom as a social value system contains a broader definition. The first is as a set of certain rules in the form of laws, rules, teachings, morality, habits or actions in accordance with the customs of society. The second is customary provisions that are locally-based on their respective identities and languages. The third is a large collection of literature from and about adat written by experts or legal experts (Lukito, 2008: 5). Hence, custom can be understood as a value system of compliance and decency which must be 
carried out by the practitioner based on the agreements made from both the previous and subsequent generations. From these customary rules, a concept of awareness about the relationship of unity between humans and nature is created. It is as a way of life and a social moral system building for Javanese as an indication of life or as the law itself.

The customary system involves various dimensions of life including natural phenomena that contain supernatural relationships because nature has supernatural powers that are mystical, and it indirectly connects the actual and spiritual dimensions. Custom as a law is not much preserved in the written tradition, but oral and action inherited from generation to generation in the united and needy macrocosmic world. The tradition is believed to be the balanced, just, and proper way of life.

In addition to an integrative relationship, Hindu also has three values of human life balance in the context of life, tatwa (falsafah), susila (ethic), and upakara. Tatwa describes one entity of God which is absolute and one or Panca Crada. Meanwhile, susila is the rules and arguments for tat twam asi and upakara as forms of ritual that oversees the trilogy of human relations. This teaching promotes a value of balance to achieve moksa, which means spiritual happiness and jagadhita, the welfare of life, and it is not indulging indrianya, lust. In I Gede Pudja's notes in Hindu philosophy, happiness requires dharma (worship), then jnana (science), and sadhana (continuous efforts) to control thoughts and behavior, and also prayascita (re-purification) (Lukito, 2008: 27). Genealogically, the part of the understanding of Javanese society is the manifestation of Hinduism, so it is possible if Javanese traditions imitate and apply some Hindu values and integrate them with their own traditions. The most basic instrumental in Javanese philosophy is appreciation and feeling to understand the reality of the nature in truth.

Interestingly, Javanese express the values in various life practices, such as sesanti, pasemon, sanepa, isbat perlambang, pralampita, wangsalan, parikan, panyandra, paribasan, bebasan, seloka, customs, and beliefs. It is a way and an effort to touch the most essential roots of life journey (Hariwijaya, 2006). Javanese understand the reality of universe as a symbolic and quasi phenomenon with multiple interpretations and values. They build their life principles based on symbolic meanings as the manifestation of supernatural values, especially to nature. The teachings of life are Javanese ethical standards to control attitudes and actions to remain consistent with universal goodness as a noble human characteristic in nature conservation practices. 
The teachings of kindness in Javanese philosophy are different from formal legal rules which require external supervision through authorized institutions, but this is not the case with the Javanese. Javanese interpret the rules of life as a principle and commitment to one's life with humans. Endaswara (2010: 35) explained that: "Javanese ethic is very unique and different from that of Western because it has a distinctive picture of humans, individuals, society and the universe. There is no obligation to obey the rules, but it is our conscience, our deepest subtle feelings that tell us to follow them". This statement further reinforces the view of how the Javanese people have an existential and conceptual power towards the preservation and use of nature to meet the needs of life. Javanese value systems that regulate the relationship between humans and the natural environment.

Based on genealogical tracking, the ecosystems concept through understanding of ruh seems that Islam and Java can acculturate to read and understand (verstehen) each other. Islam broadly explores the concept of unity in an integral part of human life in a synergistic manner, which is human relationship with God (hablum minallah), relationship between humans (hablum minannas) and (hablum minal bi'ah). In fact, fundamentally in the teachings of religion (theology), faith is a powerful stimulus that can overcome the natural ecosystem in which people with deep faith do not see the nature as an object but a partner.

On the other hand, Javanese are models of society with a very high civilization not only from Hinduism and Buddhism but also Islam. The last religion provides an affirmation of the religious social life's meaning which remains uniquely Javanese with restitution in everything, like in theology, social, culture, and economy. That is why Javanese civilization is very tied with Islamic traditions. Accordingly, the Javanese paradigm engenders to a socio-religious form known as Islam Jawa.

Java-Islam community has unique characteristics which can be seen from several characteristics including variants of their ritual practice, and the interpretation of Javanese Muslims towards ritual (Suwito, 2015). It is undeniable that Islamic approach to Java is an acculturation by developing Islamic teachings that are more Sufi. The method of tasawuf, which is known as the sect of love, invites Javanese to learn more about Islamic teachings by Muslim traders through sea trade routes. It does not take a long time for Islam to be almost believed as an approach to understanding the realities of life that is more genuine, replacing animism and dynamism. 
Tasawwuf approach consciously synergizes with Javanese who are Zuhud. In this way, they understand the depth of feeling to know their true identity. The aspect of mysticism which is strongly tied within is actualized in their socio-cultural system in relation to beliefs, levels of appreciation, and material deepening. When Islam comes with the concept of tasawwuf, Javanese accept it easily without viciousness. Then, the concept of interdependence between God, human and nature comes up. Destroying nature means hurting God's commands and humans, in which mutualism symbiosis between humans and the universe grows as a mystical spiritual depth.

The concept of ruh in Javanese affirms socio-theological value system in Javanese philosophy or idealism of life which is rich in meaning, not limited to factual and material aspects but also theological-transcendental ones. One of the expressions related to the current discussion is Eling Sangkan Paraning Dumadi, which means remembering the origin and purpose of life (Suratno $\&$ Astiyanto, 2004). This view of life teaches about the meaning of human origins and the purpose of life. For Javanese, knowing identity is the most essential effort in understanding the meaning of life purpose. They believe that the origin of human is the image of God and will then return to Him. Javanese see humans as creatures and there should eventually the One who creates (urip ono sing nguripke). They live in the dimensions of the glory and perfection of God's character. This feeling motivates them to live under God's will, not based on humans. Therefore, the life of Javanese is always oriented towards universal goodness, not materials for life.

This view of life is explained in the expression urip mung mampir ngombe (life is a drop by for a drink). This view explains and affirms that living life only with pleasure is actually a false pleasure which is not eternal. World ownership, such as wealth and social status, is temporary and will disappear then. All the world's beautiful ornaments are limited by time throughout the life of a human being. It is different after death. Javanese believe that life after death is the true encounter with God, there is no eternity except God Himself. This understanding is in line with the value of Javanese to be good during life as a provision for "being accepted" by God's side.

Human actions in the understanding of Javanese society will make great influence, depending on the goodness and badness of the act itself. In Javanese expression, sopo nandur bakal ngundhuh, which means whoever plants will pick. Life is a choice whether to prepare provisions for good or bad. Thus, they understand that every detail of life is under the control of Allah. With 
the awareness of God's presence, a person will think again if s/he does bad things in various actions. Therefore, the expression sangkan paraning dumadi becomes a monitoring tool to always be careful in living life to avoid badness and misery. They also feel that humans are only tasked with carrying out God's orders in the earth and $\mathrm{He}$ is also the one who decides, urip sadrema nglakoni sekaligus Gusti kang wenang nemtokake.

This discussion views the other model of Islam and Java integration in the context of nature conservation, which have a significant role in maintaining the ecology of the living things. Life and living with the material (horizontal) and spiritual (vertical) dimensions is actually an attitude of maintaining and preserving the environment, which is a form of worship and gratitude to God, the Creator.

\section{Conclusion}

The preservation of forest ecosystems is a public responsibility regardless of religious identity, ethnicity, race or belief because they are the big home for humans and also for survive. Islam mandates the universe and its contents to utilize without continuous exploitation. Theologically, nature is created on the basis of love and affection, so the approach to the preservation of forest ecosystems must be built on the basis of love through spiritual Sufism.

Naturally, humans have been provided with a sense of love when the spirit is granted at the first time because it comes from The Lover. Cultivating a sense of love within the heart to preserve the nature is an action step to identify one's identity about the meaning of who and where to go. That fundamental feeling is popular in Javanese as "Sangkan Paraning Dumadi" used for thinking and taking an action, especially in the context of utilizing nature. The concept of spirit in Islam and Java holds the same goal, which is to make forest sustainable with unique spiritual powers signified in values , attitudes, and perspectives on the potentials of nature. In this sense, Islam and Java are integrated in a socio-religious custom in developing awareness of natural ecosystems. 


\section{References}

Abdullah, M. M. (2003). Al Handasatu al Waritsiyah fi al-Qur'an: wa Asraru al-Ruh wa Khallaqa al Insan. Mesir: Maktaban Iman.

Afrianti, D. (2019). Transformation of the Spread of the Manunggaling Kawula lan Gusti Concept in Javanese Society from the 16th Century AD to the 21st Century AD. International Journal of Islamic Khazanah, 9(1), 29-34.

Akib, M. (2014). Hukum Lingkungan; Perspektif Global dan Nasional. Jakarta: Rajawali Press.

Al-Jamal, H. 'Izzuddin bin 'Abdul F. A. (2003). Makhthutah al-Jamal: Mu'jam wa Tafsir Lughawy li Kalimat al-Qur'an. Kairo: Al- Haiah al-Mashriyah al'Amah li al-Kutub.

Ali, M., \& Elvany, A. I. (2014). Hukum Pidana Lingkungan. Yogyakarta: UII Press.

Amin, K. U. H. (2018). al Ruh wa Nafs fi al Qur'an. Turkey.

Asriyah (2010). Kajian Terhadap Pemikiran Tentang Jiwa (Al Nafs) dalam Filsafat Islam. Jurnal Adabiyah, X(2), 223-237.

Baqi', M. A. (1945). Mu'jam al Mufahras li al Fadzi al Qur'an. Mesir: Dar al Kutub.

Declaration, T. R. J. (1992). The Rio Declaration on Environtment and Development; The Statement of Principles for a Global Consensus on the Management, Consevation and Sustainable Development of All Type of Forest (Statement of Climate Principles), Agenda 21, The Framework Convention. Brazil.

Endaswara, S. (2010). Etika Hidup Orang Jawa. Yogyakarta: Narasi.

Hariwijaya, M. (2006). Filsafat Jawa. Yogyakarta: Gelombang Pasang.

Ikhwan, M. N. (2003). Meretas Kesarjanaan Kritis Al-Qur'an. Jakarta: Teraju.

Isfahani, M. R. al. (n.d.). Mu'jam al Mufradat fi Gharib al Qur'an. Beirut: Dar al-Fikr.

Jauzi, I. Q. al. (1441). Kitab al Ruh. Beirut: Dar Alam al Fawaid.

Jumantoro, T., \& Amin, S. M. (2005). Kamus Tasawwuf. Yogyakarta: Amzah. 
Khalimi, K., \& Khaer, A. (2013). Tata Nilai Perdamaian Sufistik Jawa Cerita Pewayangan. Jurnal Pendidikan dan Kebudayaan, 19(1), 18-30.

Kholil, A. (2007). Islam Jawa. El-Harakah, 9(2), 87-99.

Koch, P. B. (2020). Mysticism, Pietism, Morality: An Introduction. European Journal of Jewish Studies, 1(aop), 1-8.

Lukito, R. (2008). Tradisi Hukum di Indonesia. Yogyakarta: Teras.

Mangunjaya, F. (2007). Menanam Sebelum Kiamat. Jakarta: Obor.

Muqoyyidin, A.W. (2013). Dialektika Islam dan Budaya Lokal Jawa. Ibda: Jurnal Kebudayaan Islam, 11(3).

Muqoyyidin, A.W. (2012). Dialektika Islam dan Budaya Lokal dalam Bidang Sosial sebagai Salah Satu Wajah Islam Jawa. El-Harakah, 14(1), 18-33. https://doi.org/10.18860/el.v0i0.2197

Naim, N. (2013). Kebangkitan Spiritualitas. Kalam, 7(2), 237-258.

Nashichuddin, A. (2006). Sufisme in Java: The Meeting Point beetween Sufism and Javanese Mysticism. El Harakah, 8(1), 43-51.

Nasution, N. (1999). Filsafat Islam. Jakarta: Gaya Media Pratama.

Purwadi. (2011). Kearifan Sufisme dalam Islamisasi Jawa. Jurnal Kebudayaan Islam Ibda', 9(1), 113-125.

Quthb, S. (2012). Afrah al Ruh. Beirut-Lebanon: Dar Ibn Hazm.

Rahmadi, T. (2014). Hukum Lingkungan di Indonesia. Jakarta: Rajawali Press.

Rosyidi, A. W. (2012). Doa dalam Tradisi Jawa. El Harakah, 14(1), 88-100.

Rubaidi. (2019). Javanese Islam ; a Blend of Javanese Culture and Islamic Mysticism Viewed from Post-Colonial Perspective. El Harakah, Vol. 21(No. 1 Tahun), 19-36. https://doi.org/DOI: http://dx.doi.org/10.18860/ el.v21i1.6066

Sartini, Ahimsa-Putra, H. S., \& Al-Makin. (2016). A Preliminary Survey on Islamic Mysticism in Java. Analisis, 16(2), 1-40. 
Setiawati, D. (2019). Slametan dalam Spiritualitas Orang Jawa pada Masa Lalu sampai Sekarang. Jurnal Pendidikan Sejarah Dan Sosiologi, 1(1), 76-88.

Sumbulah, U. (2012). Islam Jawa Dan Akulturasi Budaya; Karakteristik, Variasi dan Ketaatan Ekspresif. El Harakah, 14(1), 51-68.

Suratno, P. \& Astiyanto, H. (2004). Gusti Ora Sare. Yogyakarta: Adi Wacana.

Surtha, I. D. M. (2015). Hukum dan Sanksi Adat. Malang: Setara Press.

Suwito, S., Hidayat, A., \& Agus, S. (2015). Tradisi dan Ritual Kematian. Jurnal Kebudayaan, 13(2), 6-25.

Taymiyah, T. I. (1988). Risalat fi al Aqli Wa al Ruh (2nd ed.). Damaskus: Dar al Hijrah.

Wahidi, A. (2013). Mistisisme Sebagai Jembatan menuju Kerukunan Umat Beragama. Jurnal Ulul Albab, 14(2), 135-146.

Warassih, E., \& Fatimah, P. R. (2018). Empowering Local Wisdom in Regional Mining Policies: Study in Pati Regency, Central Java. Environmental Policy and Law, 48(5), 317-322.

Zaini, M. S. R. (1995). Mu'jam al Mufahras li Ma'anil Qur'an (1st ed.). BeirutLebanon: Dar al Fikri.

Zakub, R., Widodo, S. T., \& Setiawan, B. (2018). The Relevance between Javanese Pitutur Luhur and Islam Religiosity. IBDA: Jurnal Kajian Islam dan Budaya, 16(1).

Zuhri, A. (2010). Mbah Munawar, Tasawwuf dan Kelestarian Lingkungan. Jurnal Penelitian, 7(2), 1-10. 